\title{
Efficacy and safety of fibrin sealant for tissue adherence in facial rhytidectomy
}

REVIEW

This article was published in the following Dove Press journal:

Clinical, Cosmetic and Investigational Dermatology

23 May 2012

Number of times this article has been viewed

\section{William D Spotnitz}

The Surgical Therapeutic Advancement Center, Department of Surgery, University of Virginia Health System, Charlottesville, VA, USA
Correspondence: William D Spotnitz University of Virginia Health System, PO Box 801370, Hospital Drive, Barringer Building, 4th Floor, Room 436I, Charlottesville, VA 22908-1370, USA

$\mathrm{Tel}+\mathrm{I} 43424303$ I5

Fax +I 4342430318

Email wspotnitz@virginia.edu

\begin{abstract}
The purpose of this review is to clarify the present use of fibrin sealant in rhyditectomy procedures and help maximize the appropriate and safe application of this material. A set of terms and definitions for hemostats, sealants, and adhesives based on group, category, and class will be employed to highlight the specific capabilities of fibrin sealant. Fibrin sealant has now emerged as an example of maximizing the usefulness of a surgical agent and is the only product with Food and Drug Administration approval in all three groupings: hemostats; sealants; and adhesives. A variety of manufacturers' fibrin sealant products are available including multiple liquids and one patch. A single liquid product is now specifically indicated for skin flap adherence during rhytidectomy. The unique characteristic of this particular two component fibrin sealant adhesive agent is its slower polymerization rate as a result of a low thrombin concentration which when combined with fibrinogen permits adequate time for manipulation of flaps and tissues prior to final fixation. In addition to its flap adherence and potential space elimination capability, fibrin sealant is also an excellent blood clotting agent and can seal tissues to prevent lymphatic leak or serous fluid accumulation. Thus, it is almost ideally suited to reduce the occurrence of fluid accumulation, hematomas, ecchymoses, and swelling, as well as to possibly eliminate the need for drains following rhytidectomy. A literature review of fibrin sealant in rhytidectomy is included to help define the current state of its clinical use. The author's recommendations for the best use of this material during facial procedures are also provided.
\end{abstract}

Keywords: hemostats, sealants, adhesives, blood, lymph, serous fluid

\section{Introduction}

Hemostats, sealants, and adhesives are gaining increasing acceptance in surgical practice in the United States and presently represent a multi-billion dollar industry. A set of definitions and nomenclature are helpful in order to facilitate the safest and most cost effective use of these materials. ${ }^{1-3}$ A hemostat is designed to cause blood to clot and requires the presence of blood in the operative field to be effective. Sealants work by creating a sealing barrier. They polymerize independently and may work best when blood is not present in the field. Finally, adhesives function as self polymerizing glues capable of causing tissue adherence and often work best in a relatively dry area. Importantly, although not hemostats, both sealants and adhesives can have major hemostatic effects when used to seal or glue blood vessels together as their application can prevent major blood loss. The three groups: hemostats; sealants; and adhesives can be broken down into categories (Table 1) which are named to clarify the origin of the agents within each respective category. The hemostat group for example is divided into four categories: mechanical, active, flowable, and 
Table I Nomenclature used for organizing fibrin sealants with the hemostat, sealant and adhesive groups

\begin{tabular}{|c|c|c|c|c|}
\hline $\begin{array}{l}\text { Group } \\
\text { (All) }\end{array}$ & $\begin{array}{l}\text { Category } \\
\text { (All) }\end{array}$ & $\begin{array}{l}\text { Class } \\
\text { (Fibrin sealants only) }\end{array}$ & $\begin{array}{l}\text { Brand } \\
\text { (Fibrin sealants only) }\end{array}$ & $\begin{array}{l}\text { Manufacturer } \\
\text { (Fibrin sealants only) }\end{array}$ \\
\hline \multirow[t]{4}{*}{ Hemostats } & Mechanical & Pooled human plasma liquid & Tisseel & Baxter, Westlake Village, CA \\
\hline & Active & & Evicel & Ethicon/J\&J, Somerville, NJ \\
\hline & $\begin{array}{l}\text { Flowable } \\
\text { Fibrin sealant }\end{array}$ & $\begin{array}{l}\text { Individual human plasma liquid with } \\
\text { bovine collagen and bovine thrombin }\end{array}$ & Vitagel & Orthovita, Malvern, PA \\
\hline & & $\begin{array}{l}\text { Pooled human plasma } \\
\text { and equine collagen patch }\end{array}$ & Tachosil & Baxter, Westlake Village, CA \\
\hline Sealants & $\begin{array}{l}\text { Fibrin sealant } \\
\text { PEG polymer } \\
\text { Albumin and } \\
\text { glutaraldehyde } \\
\text { Cyanoacrylate }\end{array}$ & Pooled human plasma liquid & Tisseel & Baxter, Westlake Village, CA \\
\hline Adhesives & $\begin{array}{l}\text { Cyanoacrylate } \\
\text { Albumin and } \\
\text { glutaraldehyde } \\
\text { Fibrin sealant }\end{array}$ & Pooled human plasma liquid & Artiss & Baxter, Westlake Village, CA \\
\hline
\end{tabular}

fibrin sealant. Classes of agents can also be described. ${ }^{2,3}$ For the purposes of simplification and this review, classes for the categories of the fibrin sealants only have been provided (Table 1) to facilitate understanding the role of this material in rhytidectomy. The entire classification system for all hemostats, sealants, and adhesives is available in the literature $^{2}$ including a recent update. ${ }^{3}$

Fibrin sealant was the first of many new agents approved by the Food and Drug Administration (FDA) starting in 1998 and serves as an example for several reasons. First, as the initial approved agent it helped to establish new FDA regulatory review pathways for both biologics and devices. ${ }^{3}$ Second, its introduction began to educate surgeons, academics, and marketers that proper use of this type of material actually requires some skill and education. ${ }^{4}$ Third, fibrin sealant is the only product which has achieved FDA approval in all three groups as a hemostat, sealant, and adhesive. ${ }^{5}$ Finally, the material has been demonstrated to be effective in randomized prospective multicenter clinical trials in multiple different surgical specialties. At present fibrin sealants are derived from human pooled plasma and manufacturers take multiple steps to increase safety and eliminate the possibility of viral or prion disease transmission. Fibrin sealants come in a variety of liquid formulations which may require mixing, thawing, and applicator assembly. ${ }^{1-3}$ There is one new form of fibrin sealant approved as a hemostat which combines dry fibrinogen and thrombin on an equine collagen patch and is immediately available for use out of the package. ${ }^{3}$ Fibrin sealants are among the more costly hemostats, sealants, and adhesives and the fibrin sealant patch is the most costly hemostat. ${ }^{3}$
Laboratory $^{6-8}$ and clinical ${ }^{9,10}$ evidence supporting the use of fibrin sealant as a means of simultaneously achieving hemostasis, sealing blood vessels and lymphatics, and attaching skin flaps to eliminate potential space and prevent seroma formation during neoplasm resections was published in the 1980-1990s. Clinical reports of successful use of fibrin sealant for similar indications during rhytidectomy also appeared in the plastic surgical literature at the same time. ${ }^{11-14}$

\section{Fibrin sealants}

Multiple liquid fibrin sealants are now approved by the FDA as broad label hemostats during surgical procedures (Tisseel; Baxter, Westlake Village, CA) ${ }^{15,16}$ (Evicel; Ethicon/ J\&J, Somerville, NJ) ${ }^{17}$ (Vitagel; Orthovita, Malvern, PA) ${ }^{18}$ and a patch is approved for hemostasis during cardiac surgery only (Tachosil; Baxter). ${ }^{19}$ One fibrin sealant product is approved as sealant for colon sealing at the time of colostomy closure (Tisseel). ${ }^{16}$ In addition, one fibrin sealant is approved as an adhesive for attachment of skin grafts at the time of burn wound debridement and skin flap adherence at the time of rhytidectomy (Artiss; Baxter). ${ }^{20}$ This latter material will be presented in depth in terms of safety, efficacy, usability, and cost in this review as it is the only agent approved by the FDA as an adhesive during rhytidectomy. It is notable, however, that the other liquid fibrin sealants could potentially be used off label in this same indication by first diluting the thrombin concentration in the product to less than $5 \mathrm{IU} / \mathrm{mL}$ before combining it with fibrinogen to create a slowly polymerizing adhesive. 
Finally, the ability to use an individual patient's own autologous plasma in the form of platelet rich or poor plasma as a fibrinogen source should be mentioned. This material can then be combined with free standing thrombin of bovine (Thrombin-JMI; King Pharmaceuticals, Bristol, TN), human pooled plasma (Evithrom; Ethicon/J\&J) or recombinant (Recothrom; Zymogenetics/BMS, Seattle, WA) origin to make fibrin sealant. Although not specifically approved by the FDA for producing fibrin sealant or for use in rhytidectomy flap adherence, multiple device separation systems exist for obtaining the autologous plasma from the patient's blood (Amicus ${ }^{\circledR}$; Fenwal, Round Lake, IL; Cell Saver ${ }^{\circledR}$; Haemonetics, Braintree, MA; Harvest ${ }^{\circledR}$; Smith and Nephew, Memphis, TN; Magellan ${ }^{\mathrm{TM}}$; Medtronic, Minneapolis, MN; Recover ${ }^{\mathrm{TM}}$; Biomet Biologics, Warsaw, IN; Symphony ${ }^{\mathrm{TM}}$; Depuy, Raynham, MA). Advantages of this method include reduced cost and reduction of viral or prion disease transmission risk particularly if used with recombinant thrombin. This choice of thrombin eliminates the risk of immune mediated coagulopathy associated with bovine thrombin and viral or prion disease transmission associated with pooled plasma products. Disadvantages of the use of the separation systems include the time and personnel needed to prepare the material and the lower fibrinogen concentration obtained as compared to commercial fibrin sealants. This lower fibrinogen concentration can reduce the adhesive strength of the final product. Again, it is important to decrease the concentration of the free standing thrombin used to $<5 \mathrm{IU} / \mathrm{mL}$ to slow the polymerization process of fibrinogen to fibrin in order to assure adequate time for flap manipulation.

\section{FDA approved fibrin sealant for rhytidectomy}

Artiss $^{20}$ was originally approved for the attachment of skin grafts at burn wound debridement sites without the need for anchoring sutures or staples (Figure 1). Expansion of the label to include the adherence of skin flaps during rhytidectomy was achieved in August of 2011. ${ }^{21}$ The key modification in this fibrin sealant designed specifically

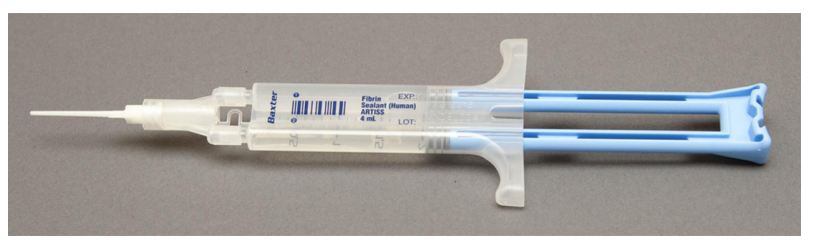

Figure I Applicator for fibrin sealant product (Artiss; Baxter, Westlake Village, CA $)^{20}$ approved for use in rhytidectomy. as an adhesive and not as a hemostat is the low thrombin concentration, $4.5 \mathrm{IU}$ (range 2.5 to $6.5 \mathrm{IU}$ ) which allows up to 60 seconds to position grafts or flaps prior to fixation. The product also contains fibrinogen, $86.5 \mathrm{mg} / \mathrm{mL}$ (range 67 to $106 \mathrm{mg} / \mathrm{mL}$ ) and aprotinin, 3,000 KIU (range 2250 to $3750 \mathrm{KIU} / \mathrm{mL}$ ).

Many of the safety issues related to the use of this product are those related to the pooled human plasma from which the fibrinogen and thrombin used in this two component adhesive are derived as well as the synthetic aprotinin which the product contains. The latter is used as a stabilizer and antifibrinolytic in the formulation. Pooled human plasma products may be potential sources for transmission of viruses including human immunodeficiency virus, hepatitis, and parvovirus B19 as well as on at least a theoretical basis transmission of prions including Creutzfeldt-Jakob disease agent. The manufacturer uses multiple strategies to reduce the risk of viral disease transmission including donor screening, testing, and pathogen reduction. ${ }^{22}$ Plasma is obtained at licensed US collection centers where high risk donors are eliminated by screening for high risk behavior. Testing of plasma includes antigen and antibody evaluation using serologic and nucleic acid techniques. Pathogen reduction steps include vapor heating and solvent detergent cleansing. Overall log viral reduction using multiple steps varies from a high of $>14.0$ for human immunodeficiency virus in thrombin to a low of 3.9 for mice minute virus (a model for parvovirus B19) in fibrinogen. No cases of AIDS or hepatitis have been documented in the literature secondary to fibrin sealant in 20 years of use. ${ }^{23}$ There have been two different literature reports of parvovirus B19 transmission secondary to fibrin sealants. ${ }^{24,25}$ Parvovirus infections may cause severe illness in patients who are pregnant, immune-compromised, or with increased erythropoiesis. The illness is characterized by fever, drowsiness, chills, and runny nose followed in two weeks by a rash and joint pains. The aprotinin used in this product is synthetic polyvalent protease inhibitor. It may be a source of hypersensitivity reactions and anaphylaxis that are more frequent on re-exposure, but can occur on first use. ${ }^{20}$ Additional safety issues with this fibrin sealant product include: air embolism associated with use of a pressurized spray applicator (recommended pressure $<20-25 \mathrm{psi}$ and distance $\geq 10-15 \mathrm{~cm}$ with further reductions in pressure required as distance decreases); graft loss secondary to application of an excessively thick layer of product; and denaturing of the product secondary to iodine, alcohol, or heavy metal ions..$^{20}$ No fibrin sealant product should ever be injected into the intravascular space to avoid the risk of thromboembolic events. 
The efficacy of this fibrin sealant adhesive product has been established in two large FDA sponsored multicenter randomized prospective clinical trials. The first demonstrated that the agent could be used successfully as compared to staples to attach skin grafts (Figure 2) in burn wound debridement patients including adults and children..$^{20,26}$ The patients served as their own controls (intent to treat 128 patients) and two grafts were placed per patient using fibrin sealant at one site and staples at the other site. Analysis of the primary endpoint, healing at day 28 by planimetry, revealed that $70.7 \%$ of fibrin sealant treated sites and $65.8 \%$ of stapled sites were judged to have been completely healed. The lower limit of the $97.5 \%$ confidence interval was less than the predetermined inferiority margin $(-0.1)$ at a value of -0.029 showing that the fibrin sealant product was non inferior to staples in this indication. Additional analysis revealed superiority of fibrin sealant over staples respectively for: hematoma formation at day 1, 29.7\% versus $62.3 \%$ $(P<0.0001)$; investigator judged wound quality measures including adherence quality, fixation method preference, satisfaction with method, and overall quality $(P<0.0001)$; and patient assessed outcomes including pain, anxiety, and treatment preference $(P<0.0001)$. There were no serious adverse events.

The second large study in patients $(\mathrm{n}=75)$ undergoing rhytidectomy demonstrated that patients had significant $(P<0.0001)$ reductions in serous fluid drainage volume in the first 24 hours on the randomly selected fibrin sealant treated side of the face, $7.7 \pm 7.4 \mathrm{~mL}$ versus the standard of care side of the face $20.0 \pm 11.3 \mathrm{~mL}{ }^{20,27} \mathrm{~A}$ trend towards a reduced number of hematomas was also noted on the fibrin sealant side of the face as compared to the standard of care

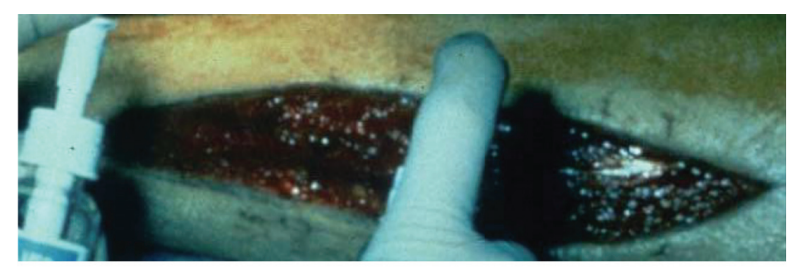

Pre-fibrin sealant adhesive

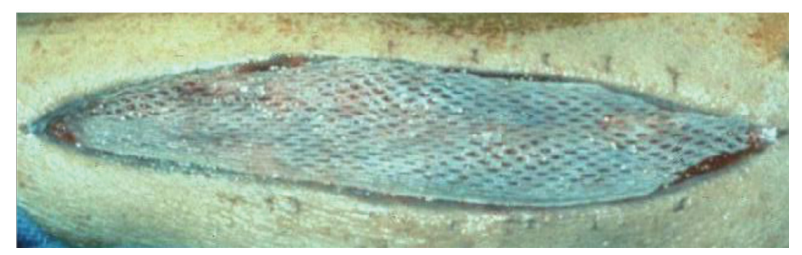

Post-fibrin selant adhesive (no sutures or staples required)

Figure 2 Placement of a split thickness skin graft using a thin layer of fibrin sealant application (top portion) without the need for staples or sutures (bottom portion). side, 2 versus 5 patients respectively. An example of this technique in head and neck surgery is illustrated (Figure 3).

The fibrin sealant adhesive product comes in 2,4 , and $10 \mathrm{~mL}$ kits which refer to the total volume of fibrin sealant produced by the kit. ${ }^{20}$ The usability of liquid fibrin sealant in general has been an impediment to adoption in the United States as some combination of thawing, mixing, and applicator assembly has been required in the past. The need for this preparation was often associated with the consternation of operating room nurses and circulators who were assigned the complex task of preparing the material. In response to this issue, the manufacturer has made efforts to reduce the difficulty of preparation. There are two available formulations of the material. The first is a freeze-dried product (stored at $2{ }^{\circ} \mathrm{C}-25^{\circ} \mathrm{C}$ ) which no longer requires thawing or refrigeration, but does still need reconstitution and applicator assembly. Mixing is facilitated using a supplied system which is most important in reconstituting the fibrinogen component (Figure 4). The product needs to be used within 4 hours of reconstitution. The second form of the product, a frozen liquid (stored at $\leq-20^{\circ} \mathrm{C}$ )

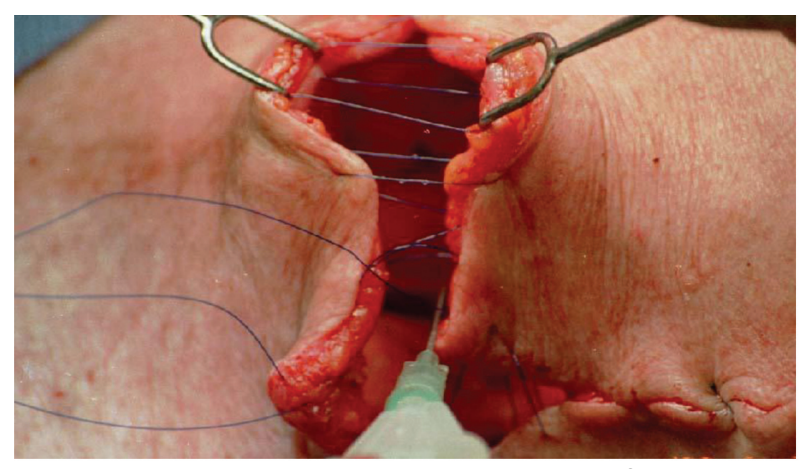

Fibrin sealant adhesive placment under flaps

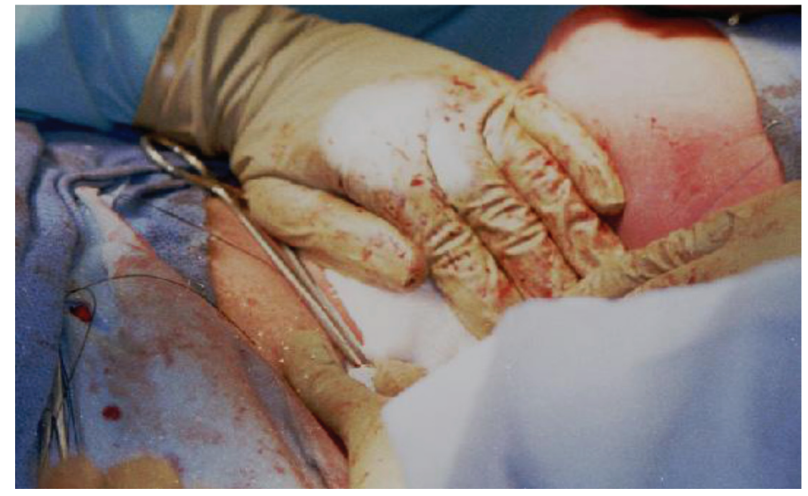

Pressure following fibrin sealant adhesive application

Figure 3 Use of fibrin sealant to attach skin flaps to underlying tissue at the time of neck dissection (top portion) and placement of gentle pressure during adhesive polymerization (bottom portion).

Modified and used with permission of Peoples Medical Publishing House - USA (PMPH-USA) from Spotnitz WD, Burks SG, Prabhu R. Fibrin based adhesives and hemostatic agents. In: James V. Quinn, editor. Tissue Adhesives in Clinical Medicine, 2nd Edition. BC Decker; 2005: 94 (Figures 4-6). ${ }^{45}$ 


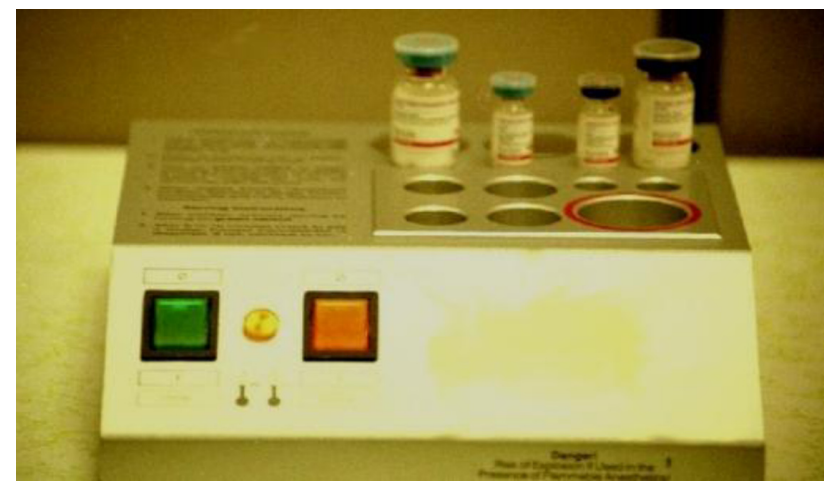

Figure 4 Manufacturer supplied Artiss device (Baxter, Westlake Village, CA) to facilitate dissolving freeze dried fibrinogen and thrombin powders in saline solutions.

in a preassembled applicator pouch, requires no mixing and minimal assembly, but does require thawing. Thawing times vary depending on kit size and method of defrosting: room air; incubator at $33^{\circ} \mathrm{C}-37^{\circ} \mathrm{C}$; or sterile or unsterile water bath at $33^{\circ} \mathrm{C}-37^{\circ} \mathrm{C}$. The fastest thawing time is 5 minutes which can be achieved using the smallest $2 \mathrm{~mL}$ kit in a warm sterile water bath at $33^{\circ} \mathrm{C}-37^{\circ} \mathrm{C}$. Unopened pouches thawed at room temperature may be stored in a refrigerator $\left(\right.$ at $\left.15^{\circ} \mathrm{C}-25^{\circ} \mathrm{C}\right)$ for periods of up to 2 weeks and then can be quickly available after a brief period of warming $\left(\right.$ at $\left.33^{\circ} \mathrm{C}-37^{\circ} \mathrm{C}\right)$. The product should never be warmed in a microwave. The applicator system (Spray Set; Baxter) ${ }^{28}$ and pressure regulator (Easyspray; Baxter ${ }^{29}$ allow for spraying a fine mist and creating a thin tissue layer of applied material. A variety of applicators for spray or drip application are available (Figure 5). A thin layer of material should be applied to avoid formation of excess granulation tissue ${ }^{20}$ as well as to allow for skin graft nutrient diffusion. ${ }^{30}$ The graft or flap should be placed on top of the fibrin sealant immediately after application. Manipulation or repositioning is possible for only the first 60 seconds which should then be followed by 3 minutes of gentle pressure. Any further manipulations of the graft or flap need to be avoided to prevent disruption of the fibrin sealant adhesive bond.

This fibrin sealant is priced competitively to other liquid fibrin sealants on the market and costs approximately $\$ 50$ per $\mathrm{mL}$ of final fibrin sealant product.

\section{Literature review}

In addition to the FDA sponsored trials already discussed, the advantages of using fibrin sealant in rhytidectomy have been described in the literature for at least 30 years. ${ }^{11}$ Case reports, ${ }^{11,12,31}$ large series,,${ }^{13,14,32-35}$ and randomized prospective trials ${ }^{27,36,37}$ support the value of using fibrin sealant in rhytidectomy. Several investigators question some of
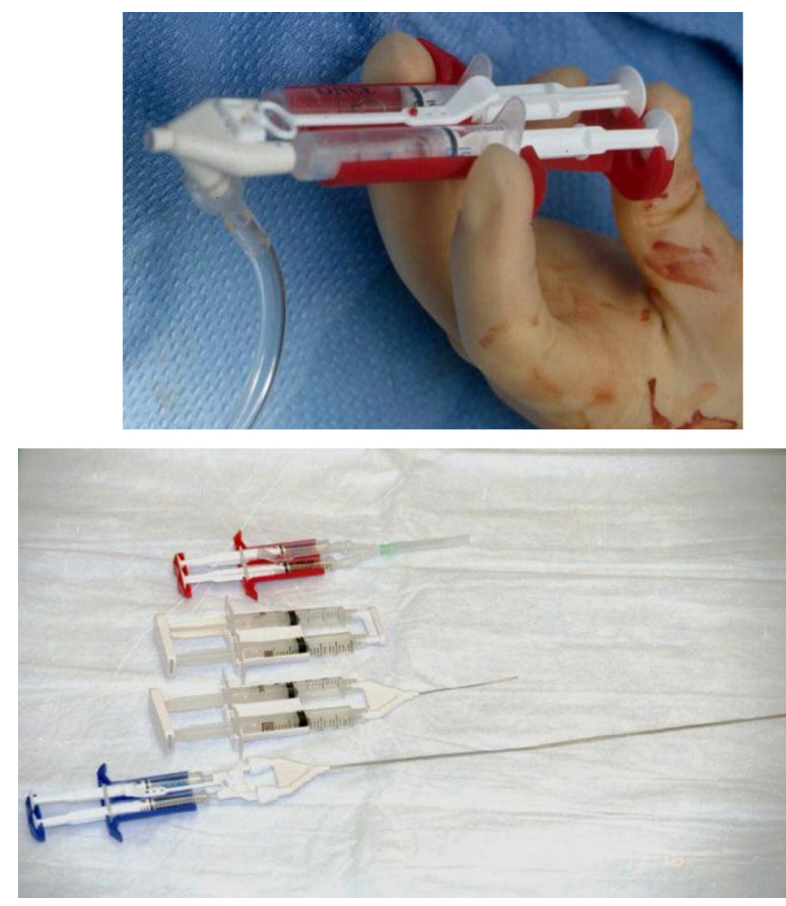

Figure 5 Some spray (top portion) and cannula (bottom portion) type applicators which can be used for application of fibrin sealant.

the reported advantages of this material. ${ }^{38-40}$ The literature also contains data ${ }^{41}$ and a recent review ${ }^{42}$ supporting the use platelet gels as an alternative to fibrin sealant in rhytidectomy. A review of tissue glue use in plastic surgery also addresses the best use of fibrin sealant and platelet gels in a variety of different facial aesthetic procedures. ${ }^{43}$

Benefits of using fibrin sealant in individual patient reports include reduced: number of sutures; ${ }^{11}$ extent of swelling; ${ }^{11}$ amount of serous fluid secretions ${ }^{11}$ hematoma formation; ${ }^{12}$ operating time; ${ }^{12}$ need for drains; $;{ }^{12,13}$ and recovery time. ${ }^{12}$

Advantages to using fibin sealant in a large series using historical controls included statistically significant reductions in major hematomas and ecchymosis as well as the ability to use no drains at all. ${ }^{13}$ In a sequential endoscopic series using fibrin sealant for proper brow fixation, a significant improvement in the last 69 patients compared to the first 28 patients was found for eye brow positioning and muscle weakening ${ }^{14}$ highlighting the fact that there may be a learning curve for the use of fibrin sealant. ${ }^{4}$ In another sequentially controlled series of first using no fibrin sealant with drains followed by aerosolized fibrin sealant without drains in facelift surgery, ${ }^{32}$ significant reductions were found in bruising and swelling $(P<0.0001)$ as well as operating room time by 13 minutes $(P<0.0001)$. No statistically significant reductions in hematomas were found. A faster recovery time was found in another sequentially controlled series of short 
scar face-lift procedures using fibrin sealant. ${ }^{33}$ In another historically controlled $(n=100)$ trial with prospectively enrolled patients $(\mathrm{n}=100)$ undergoing rhytidectomy with fibrin sealant, ${ }^{34}$ significant reductions were seen using fibrin sealant in: hematoma rate, $1 \%$ versus $3 \%(P<0.05)$; and prolongued induration, edema, and ecchymosis, $0 \%$ versus $22 \%(P<0.05)$. No advantages were found for using fibrin sealant in pain score and patient satisfaction. In a retrospective comparison of deep-plane face-lift surgery with $(n=459)$ and without $(\mathrm{n}=146)$ fibrin sealant, ${ }^{35}$ adhesive treatment was associated with a significantly reduced hematoma rate, $0.45 \%$ versus $3.4 \%(P=0.01)$.

In a prospective, randomized series with the patients $(n=20)$ serving as their own controls by randomly varying the sides of the face treated with fibrin sealant, ${ }^{36}$ a significant reduction in 24 hours of postoperative drainage prior to drain removal was found in the treated sides, $10 \mathrm{~mL}$ versus $30 \mathrm{~mL}(P=0.002)$. In a small, FDA sponsored, single institution, randomized, prospective trial of patients $(n=9)$ with pressure dressings applied to all patients, reviewers blinded to treatment, and randomly varying the side of the face treated with fibrin sealant (Crosseal; Omrix, Brussels, Belgium $),{ }^{37}$ a significant reduction in the treated patient sides was found for ecchymosis score, 4.5 versus $6.2(P<0.01)$. No significant reductions in hematoma or seroma formation were found.

Several investigators have published data suggesting the lack of effectiveness of fibrin sealant in rhytidectomy. In a large retrospective study of 678 patients undergoing face-lifts, ${ }^{38}$ the effect of dressings, drains, and tumescence on hematoma formation was evaluated. No reduction in hematoma rate was found for the use of fibrin sealant. In a randomized, prospective trial of using fibrin sealant in face-lifts, ${ }^{39}$ treated patient sides had a significant reduction in postoperative drainage volume, $26 \mathrm{~mL}$ versus $33.5 \mathrm{~mL}$ ( $P=0.037$ ), but this change of $7.5 \mathrm{~mL}$ was not thought to be surgically important. No reduction in hematomas on the treated sides was found. Finally, a meta-analysis of three, randomized, controlled, fibrin sealant trials ${ }^{40}$ found a strong trend towards reduction in postoperative drainage and ecchymosis at 24 hours, but no reduction in edema.

Both a study ${ }^{41}$ and a recent review ${ }^{42}$ support the use of platelet gels (patient's own plasma and platelets used as a low concentration fibrinogen source combined with a free standing thrombin to create a fibrin sealant like material thought to have augmented value as result of growth factors in platelets) in rhytidectomy. In the retrospective, historically controlled study ${ }^{41}$ the platelet gel treated patients $(n=19)$ had a significant reduction of $35 \%(P<0.03)$ in postoperative drainage volume at 8 hours as compared to control patients $(\mathrm{n}=14)$ who received no platelet gel.

Clearly, the literature shows a wide variation in results for the application of fibrin sealant in rhytidectomy with the most consistent and best results demonstrated in reduction of fluid drainage while less reproducible results being reported for reduction of hematomas, ecchymoses, and edema. Some of this variation may be as a result of using different materials and application techniques. The next section will review some of the author's suggestions for maximizing the effectiveness of fibrin sealant during rhytidectomy.

\section{Author's suggestions for use}

Suggestions for hemostasis creation, pre sealant preparation, sealant application, post sealant treatment, and postoperative care are provided (Table 2). The single most important concept is that the use of fibrin sealant needs to be planned as an integral part of the operation and not just as a mere additional adjunct. To gain the maximum benefit from the use of this adhesive multiple other steps need to be organized in a coordinated and timely fashion.

Hemostasis is critically important in order to avoid hematomas which may contribute to ecchymoses and delayed healing. When fibrin sealant liquid is used as a hemostat employing a higher concentration of thrombin $(>500 \mathrm{IU} / \mathrm{mL}$ ), the material is indicated for hemostasis of bleeding which is non suturable and non cauterizable. Fibrin sealant is not a substitute for meticulous surgical technique. Thus, in rhytidectomy, all bleeding that can be treated by conventional methods should be addressed prior to using the fibrin sealant as a slowly polymerizing adhesive employing a low thrombin concentration $(<5 \mathrm{IU} / \mathrm{mL})$. Any hemostatic benefits to using the fibrin sealant in this setting may be as a result of a sealing effect which may help to keep small vessels closed as vasospasm subsides after the procedure.

Prior to using the fibrin sealant all preparations should be made to avoid further manipulations of the flaps or skin following adhesive application. Thus, all skin flaps should be measured and trimmed. All sutures should be in place including anchoring sutures which then should be tied as soon as possible after application of the fibrin sealant. Any suture lines should be preplaced as a lattice work (Figure 3, top portion) which can be quickly tightened after sealant application. If drains are to be placed, they should be in position prior to fibrin sealant application and should be protected so as not to be clogged by the addition of the adhesive. The drains may become unnecessary as experience and 
Table 2 Author's suggestions provided for the proper use of fibrin sealant during rhytidectomy

\begin{tabular}{ll}
\hline Subject & Authors' specific suggestions \\
\hline Hemostasis & - Assure meticulous hemostasis as fibrin sealant is most effective at sealing small vessels and will not prevent hemorrhage from \\
& vessels requiring suture or cautery \\
Pre sealant & - Cut all skin flaps and place all skin sutures in advance of fibrin sealant application \\
preparation & - Place fixation sutures and tie immediately after application of fibrin sealant \\
& - Place lattice work of sutures for all suture lines which can be rapidly tightened after application of fibrin sealant \\
& - Place drains if they are going to be used prior to fibrin sealant application \\
- Avoid clogging of drains with fibrin sealant \\
- Avoid drains altogether after gaining experience and confidence in the use of fibrin sealant \\
application & - Apply fibrin sealant to all portions of flaps using appropriate length cannulas or spray devices \\
& - Apply fibrin sealant as a thin layer and avoid excessive thickness which may contribute to additional granulation tissue formation \\
Post sealant & and delayed flap healing as well as to skin graft necrosis by interfering with diffusion of nutrients from underlying tissues \\
application & - Apply gently pressure to flaps for at least 3 minutes and consider the use of pressure dressings \\
& - Avoid any further movement or manipulation of facial skin or flaps after application of pressure including placement of any \\
& additional sutures or lifting of tissues with forceps as disruption of initial fibrin sealant bonding will cause sealant to function \\
Postoperatively & as anti-adhesive and even stimulate seroma formation and fluid drainage \\
& Prevent arterial hypertension as well as prevent and treat nausea and vomiting to avoid any increases in venous pressure and \\
& minimize potential for additional bleeding
\end{tabular}

confidence in the method of fibrin sealant use is gained and the drains can then be omitted altogether.

During the application of fibrin sealant itself, it is important to assure that all flaps and surfaces are covered with the adhesive using appropriate length cannulas or spray devices (Figure 5). The adhesive should be applied as an even thin layer to facilitate the maximum rate of flap healing and to facilitate nutrient diffusion in order to avoid graft tissue necrosis. After the placement of the sealant, the flaps should be quickly positioned and adjusted as necessary so that any manipulation can be avoided after the first 60 seconds of polymerization time.

As soon as possible after application of fibrin sealant, gentle pressure should be applied to all flaps (Figure 3, bottom portion) for at least 3 minutes to assure bonding between the flap and underlying tissues. Pressure dressings may be useful in helping to assure this bonding as well. It is critical not to do any further flap or skin manipulation after this period of initial bonding. The lifting of skin for placement of additional sutures or manipulation with forceps as well as any further movement of the flaps needs to be strictly avoided. This is necessary because breaking of the fibrin sealant bonds at this point will create a smooth non sticky polymerized fibrin sealant interface between the flap and underlying tissues which has been shown to be an excellent anti-adhesive. ${ }^{44}$ The placement of an anti-adhesive in this location may actually increase the formation of seromas and fluid drainage.

Finally any postoperative events that might stimulate bleeding should be avoided. Thus clearly arterial hypertension should be minimized and nausea and vomiting should be prevented if possible and treated if present to decrease the potential for venous pressure elevation.

\section{Conclusions}

Fibrin sealant is an important addition to the surgeons' armamentarium and is useful in rhytidectomy. This review has characterized the material and provided a nomenclature for understanding the capabilities of this unique hemostat, sealant, and adhesive. The use of fibrin sealant in rhytidectomy and the currently approved product for this indication have been reviewed in depth. The author's suggestions to facilitate the most effective use of the agent have been provided and it should be emphasized that there is a gentle learning curve to master in order to use this powerful multiple capacity product most effectively.

\section{Disclosures}

There are or have been recent consulting agreements for the services of the author between the University of Virginia and Baxter, Bayer, Biom'Up, Covidien, Cubist, Ethicon/J\&J, Lifebond, Luna Innovations, Medafor, Neomend, Profibrix, SEAlantis, and Zymogenetics/BMS.

\section{References}

1. Spotnitz WD, Burks S. Hemostats, sealants, and adhesives: components of the surgical toolbox. Transfusion. 2008;48(7):1502-1516.

2. Spotnitz WD, Burks S. State-of-the-art review: Hemostats, sealants, and adhesives II: Update as well as how and when to use the components of the surgical toolbox. Clin Appl Thromb Hemost. 2010;16(5): 497-514.

3. Spotnitz WD, Burks S. Hemostats, sealants, and adhesives III: A new update as well as cost and regulatory considerations for components of the surgical toolbox. Transfusion. 2012. In press. 
4. Wang GJ, Goldthwaite CA Jr, Burks SG, Spotnitz WD; Orthopaedic Research Group. Experience improves successful use of fibrin sealant in total knee arthroplasty: implications for surgical education. $J$ Long Term Eff Med Implants. 2003;13(5):389-397.

5. Spotnitz WD. Fibrin sealant: past, present, and future: a brief review. World J Surg. 2010;34(4):632-634.

6. Lindsey WH, Masterson TM, Llaneras M, Spotnitz WD, Wanebo HJ, Morgan RF. Seroma prevention using fibrin glue during modified radical neck dissection in a rat model. Am J Surg. 1988;156(4):310-313.

7. Lindsey WH, Masterson TM, Spotnitz WD, Wilhelm MC, Morgan RF. Seroma prevention using fibrin glue in a rat mastectomy model. Arch Surg. 1990;125(3):305-307.

8. Sanders RP, Goodman NC, Amiss LR Jr, et al. Effect of fibrinogen and thrombin concentrations on mastectomy seroma prevention. J Surg Res. 1996;61(1):65-70.

9. Moore MM, Nguyen DH, Spotnitz WD. Fibrin sealant reduces serous drainage and allows for earlier drain removal after axillary dissection: a randomized prospective trial. Am Surg. 1997;63(1):97-102.

10. Moore M, Burak WE Jr, Nelson E, et al. Fibrin sealant reduces the duration and amount of fluid drainage after axillary dissection: a randomized prospective clinical trial. J Am Coll Surg. 2001;192(5): 591-599.

11. Bruck HG. Fibrin tissue adhesion and its use in rhytidectomy: a pilot study. Aesthetic Plast Surg. 1982;6(4):197-202.

12. Flemming I. Fibrin glue in face lifts. Facial Plast Surg. 1992;8(1): 79-88.

13. Marchac D, Sándor G. Face lifts and sprayed fibrin glue: an outcome analysis of 200 patients. Br J Plast Surg. 1994;47(5):306-309.

14. Marchac D, Ascherman J, Arnaud E. Fibrin glue fixation in forehead endoscopy: evaluation of our experience with 206 cases. Plast Reconstr Surg. 1997;100(3):704-712.

15. Baxter Announces FDA Approval of Expanded Indication for TISSEEL. Baxter Press Release. January 30, 2012. http://medicalhemostat. blogspot.com/. Accessed April 18, 2012.

16. Package Insert. Tisseel, Baxter. 2012. http://www.fda.gov/downloads/ BiologicsBloodVaccines/BloodBloodProducts/ApprovedProducts/ LicensedProductsBLAs/FractionatedPlasmaProducts/ucm072968.pdf. Accessed April 18, 2012.

17. Package Insert. Evicel, Ethicon/J\&J. 2009. http://www.fda. gov/downloads/BiologicsBloodVaccines/BloodBloodProducts/ ApprovedProducts/LicensedProductsBLAs/FractionatedPlasma Products/ucm114073.pdf. Accessed April 18, 2012.

18. Summary of Safety and Effectiveness Data. Vitagel, Orhtovita. 2006. http://www.accessdata.fda.gov/cdrh_docs/pdf5/P050044b.pdf. Accessed April 18, 2012.

19. Package Insert. Tachosil, Baxter. 2010. http://www.fda.gov/downloads/ BiologicsBloodVaccines/BloodBloodProducts/ApprovedProducts/ LicensedProductsBLAs/FractionatedPlasmaProducts/UCM207483. pdf. Accessed April 18, 2012.

20. Package Insert. Artiss, Baxter. 2011. http://www.fda.gov/downloads/ biologicsbloodvaccines/bloodbloodproducts/approvedproducts/ licensedproductsblas/fractionatedplasmaproducts/ucm073054.pdf. Accessed April 18, 2012.

21. Summary Basis for Regulatory Action. FDA. August 8, 2011. http://www. fda.gov/downloads/BiologicsBloodVaccines/BloodBloodProducts/ ApprovedProducts/LicensedProductsBLAs/FractionatedPlasma Products/UCM271593.pdf. Accessed April 18, 2012.

22. Horowitz B, Busch M. Estimating the pathogen safety of manufactured human plasma products: application to fibrin sealants and to thrombin. Transfusion. 2008;48(8):1739-1753.

23. Joch C. The safety of fibrin sealants. Cardiovasc Surg. 2003;11 Suppl 1: 23-28.

24. Hino M, Ishiko O, Honda KI, Yamane T, et al. Transmission of symptomatic parvovirus B19 infection by fibrin sealant used during surgery. Br J Haematol. 2000;108(1):194-195.
25. Kawamura M, Sawafuji M, Watanabe M, Horinouchi H, Kobayashi K. Frequency of transmission of human parvovirus B19 infection by fibrin sealant used during thoracic surgery. Ann Thorac Surg. 2002;73(4): 1098-1100.

26. Foster K, Greenhalgh D, Gamelli RL, et al; FS 4IU VH S/D Clinical Study Group. Efficacy and safety of a fibrin sealant for adherence of autologous skin grafts to burn wounds: results of a phase 3 clinical study. J Burn Care Res. 2008;29(2):293-303.

27. Rohrich RJ, Shire JR, Desmond JC. Artiss improves flap adherence following rhytidectomy through full surface adherence between the wound bed and applied tissue which eliminates areas of dead space often associated with hematoma and seroma: results of a phase 3, multicenter, prospective, randomized clinical study. Paper presented at : American Association of Plastic Surgeons (AAPS) 90th Annual Meeting, Boca Raton, FL, April 9-12, 2011.

28. Instructions for Use. Spray Set, Baxter. http://www.baxterbiosurgery. com/resources/pdfs/TISSEEL_Spray_Set_IFU_Final.pdf. Accessed April 18, 2012.

29. Instructions for Use. Easyspray Pressure Regulator, Baxter. http://www. baxterbiosurgery.com/resources/pdfs/TISSEEL_EasySpray_IFU_final. pdf. Accessed April 18, 2012.

30. O'Grady KM, Agrawal A, Bhattacharyya TK, Shah A, Toriumi DM. An evaluation of fibrin tissue adhesive concentration and application thickness on skin graft survival. Laryngoscope. 2000;110(11): 1931-1935.

31. Panfilov DE. MIDI face-lift and tricuspidal SMAS-flap. Aesthetic Plast Surg. 2003;27(1):27-37.

32. Fezza JP, Cartwright M, Mack W, Flaharty P. The use of aerosolized fibrin glue in face-lift surgery. Plast Reconstr Surg. 2002;110(2): 658-664.

33. Matarasso A, Rizk SS, Markowitz J. Short scar face-lift with the use of fibrin sealant. Dermatol Clin. 2005;23(3):495-504, vii.

34. Kamer FM, Nguyen DB. Experience with fibrin glue in rhytidectomy. Plast Reconstr Surg. 2007;120(4):1045-1051.

35. Zoumalan R, Rizk SS. Hematoma rates in drainless deep-plane face-lift surgery with and without the use of fibrin glue. Arch Facial Plast Surg. 2008;10(2):103-107.

36. Oliver DW, Hamilton SA, Figle AA, Wood SH, Lamberty BG. A prospective, randomized, double-blind trial of the use of fibrin sealant for face lifts. Plast Reconstr Surg. 2001;108(7):2101-2105.

37. Lee S, Pham AM, Pryor SG, Tollefson T, Sykes JM. Efficacy of Crosseal fibrin sealant (human) in rhytidectomy. Arch Facial Plast Surg. 2009;11(1):29-33.

38. Jones BM, Grover R. Avoiding hematoma in cervicofacial rhytidectomy: a personal 8-year quest. Reviewing 910 patients. Plast Reconstr Surg. 2004;113(1):381-387.

39. Marchac D, Greensmith AL. Early postoperative efficacy of fibrin glue in face lifts: a prospective randomized trial. Plast Reconstr Surg. 2005;115(3):911-916.

40. Por YC, Shi L, Samuel M, Song C, Yeow VK. Use of tissue sealants in face-lifts: a metaanalysis. Aesthetic Plast Surg. 2009;33(3):336-339.

41. Brown SA, Appelt EA, Lipschitz A, Sorokin ES, Rohrich RJ. Platelet gel sealant use in rhytidectomy. Plast Reconstr Surg. 2006;118(4): 1019-1025.

42. Farrior E, Ladner K. Platelet gels and hemostasis in facial plastic surgery. Facial Plast Surg. 2011;27(4):308-314.

43. Toriumi DM, O'Grady K. Use of surgical tissue adhesives in facial plastic surgery. In: Saltz R, Toriumi DM, editors. Tissue Glues in Cosmetic Surgery. Quality Medical Publishing; 2004:88-109.

44. Harris ES, Morgan RF, Rodeheaver GT. Analysis of the kinetics of peritoneal adhesion formation in the rat and evaluation of potential antiadhesive agents. Surgery. 1995;117(6):663-669.

45. Spotnitz WD, Burks SG, Prabhu R. Fibrin based adhesives and hemostatic agents. In: James V Quinn, editor. Tissue Adhesives in Clinical Medicine, 2nd ed. BC Decker; 2005:1.94. 


\section{Publish your work in this journal}

Clinical, Cosmetic and Investigational Dermatology is an international, peer-reviewed, open access, online journal that focuses on the latest clinical and experimental research in all aspects of skin disease and cosmetic interventions. All areas of dermatology will be covered; contributions will be welcomed from all clinicians and basic science researchers globally. This journal is indexed on CAS. The manuscript management system is completely online and includes a very quick and fair peer-review system, which is all easy to use. Visit http://www.dovepress.com/testimonials.php to read real quotes from published authors.

Submit your manuscript here: http://www.dovepress.com/clinical-cosmetic-and-investigational-dermatology-journal 